\title{
Reproductive Health of Migrant Women in Slovenia: State of the Art
}

\author{
Blaž Lenarčič \\ Science and Research Centre Koper, Slovenia \\ blaz.lenarcic@zrs-kp.si

\section{Mateja Sedmak} \\ Science and Research Centre Koper, Slovenia \\ mateja.sedmak@zrs-kp.si
}

\begin{abstract}
The chapter presents the state of the art in the area of reproductive health of migrant women in Slovenia. At the beginning authors presents the demographic and socio-economic characteristics of migrant women, a review of national legislation regulating the area of reproductive health (for migrant women), a review of scientific literature and research dealing with the issue and a presentation of existing best practices. Data on the number of migrant women in Slovenia show that their number is constantly increasing (a six-fold increase between 1995 and 2016) and it is expected that it will be even higher in the future while at the same time a comprehensive and systematic approach to reproductive health in relation to migrant women is missing. The literature review and best practices overview indicate that the first and the most urgent step towards improvement of the situation in this area would be to educate health providers interculturally in order that they can recognize reproductive health norms and practices within different cultural contexts. This would allow them to provide culturally safe medical care, health education, and health promotion, and finally increase access to reproductive health for migrant women.
\end{abstract}

\section{Introduction}

The United Nations Guidelines on Reproductive Health (United Nations Population Information Network, 1994) characterize reproductive health as a state of complete physical, mental and social well-being, and not merely the absence of reproductive disease or infirmity. Furthermore, they highlight that reproductive health is an important component of general health and a prerequisite for an individual's social, economic and human development. In spite of the wide international adoption of norms and standards for the universal right to health, and reproductive health as an inseparable part of that, there remain significant gaps in access for certain groups of individuals. One such group is migrant women, who frequently confront specific challenges in this field. There is a general consensus that migrant women are an 
especially vulnerable group, which should have guaranteed early access to reproductive health services, preventive health services, health promotion, screening and diagnostic care, as well as prenatal and obstetric services. Unfortunately, as reported by Keyganert et al. (2014), compared with the general EU population, migrant women from non-EU Member States are less often screened for cervical and breast cancer, have less access to family planning and contraception and a lower uptake of gynecological care, are more at risk of unintended pregnancies, have fewer and later antenatal care visits, have poorer pregnancy outcomes and higher infant and maternal mortality rates. Because entitlements to health services are based on legal status, and because migrant women usually face communication obstacles and are subjected to discriminatory practices and lack of cultural understanding, the consequence is their limited access to a range of (reproductive) health information, goods, facilities and services (Bofulin \& Bešter, 2010).

The aim of this chapter is to present an overview of the current situation of migrant women in Slovenia with regard to reproductive health through (1) a presentation of the demographic and socio-economic characteristics of migrant women, (2) a review of national legislation regulating the area of reproductive health (for migrant women), (4) a review of scientific literature dealing with the issue and (5) a presentation of existing best practices.

\section{Demographic, Social and Economic Characteristics of Migrant Women in Slovenia}

The available statistical data' reveal a relatively low prevalence of migrant women in Slovenia. The highest percentages of migrant women are from other states of former Yugoslavia. Slovenia is not the final destination for those who, for various reasons, migrate to Europe from other continents. Slovenia is a small country, economically not very developed and less recognized in the wider political arena. Consequently, for economic, political, climate or other reasons, the number of immigrants coming to Slovenia is not high in comparison with other EU countries. The same is true when we look at the immigration of women.

In Slovenia, as already mentioned, immigration from the states of former Yugoslavia prevail, which started mostly for economic reasons back in the 1960 s and 1970 s. Slovenia faced a bigger migration wave, especially from the territory of Bosnia and Herzegovina, in the 1990 due to the war in Balkan

\footnotetext{
${ }^{1}$ Statistical data were obtained from the Slovenian national statistical agency (SURS, see http:// pxweb.stat.si).
} 
area, when more than 70,000 refugees came and some of them settled permanently, and also from Kosovo. Like other EU Members States in the last five-year period, Slovenia has also been challenged by migration flows due to the conflicts in the Middle East and Africa. However, it still remains mostly a transition country.

\section{Percentages of Migrant Women}

In the period 2011-2018 the percentage of foreigners in the overall Slovenian population has increased by $1.8 \%$ (from $4.1 \%$ to $5.9 \%$ ); in absolute terms, from 84,854 to 121,875 . In the same period, the number of foreign women increased from 25,728 to 43,019 . As a percentage of the female population, it has gone from $2.4 \%$ in 2011 to $4.1 \%$ in 2018.

In terms of statistical regions (Table 1), the presence of foreign women is highest in Central Slovenia $(40,716)$, followed by the Drava region $(161,607)$, Savinja region $(14,974)$ and Coastal-Karst region $(11,910)$. However, looking at the percentages, the highest percentage of foreign women in relation to the whole female population is registered in the Costal-Karst region (10.5\%),

Table 1 Population of the Statistical Regions of Slovenia by gender

\begin{tabular}{|c|c|c|c|c|c|c|c|c|}
\hline \multirow{2}{*}{$\begin{array}{l}\text { Statistical } \\
\text { region }\end{array}$} & \multirow[t]{2}{*}{ Total } & \multirow[t]{2}{*}{ Women } & \multicolumn{2}{|c|}{ Foreign pop. } & \multicolumn{4}{|c|}{ Foreign pop. - women } \\
\hline & & & (1) & (2) & (1) & $(2)$ & (3) & (4) \\
\hline Central Slovenia & 542,306 & 276,369 & 40,716 & 7.5 & 14,534 & 2.7 & 35.7 & 5.3 \\
\hline Drava & 322,058 & 161,607 & 16,408 & 5.1 & 5,089 & 1.6 & 31.0 & 3.1 \\
\hline Savinja & 254,760 & 126,834 & 14,974 & 5.9 & 4,828 & 1.9 & 32.2 & 3.8 \\
\hline Coastal-Karst & 113,961 & 57,536 & 11,910 & 10.5 & 4,727 & 4.1 & 39.7 & 8.2 \\
\hline Upper Carniola & 203,636 & 102,618 & 10,691 & 5.3 & 4,104 & 2.0 & 38.4 & 4.0 \\
\hline Gorizia & 117,260 & 58,552 & 6,426 & 5.5 & 2,422 & 2.1 & 37.7 & 4.1 \\
\hline $\begin{array}{l}\text { Sautheast } \\
\text { Slovenia }\end{array}$ & 142,819 & 70,752 & 6,426 & 4.5 & 2,084 & 1.5 & 32.4 & 2.9 \\
\hline Lower Sava & 75,359 & 37,431 & 4,085 & 5.4 & 1,380 & 1.8 & 33.8 & 3.7 \\
\hline $\begin{array}{l}\text { Litoral-Inner } \\
\text { Karniola }\end{array}$ & 52,334 & 25,864 & 3,369 & 6.4 & 1,216 & 2.3 & 36.1 & 4.7 \\
\hline Central Sava & 57,061 & 28,878 & 2,406 & 4.2 & 941 & 1.6 & 39.1 & 3.3 \\
\hline Charintia & 70,550 & 35,131 & 2,539 & 3.6 & 890 & 1.3 & 35.1 & 2.5 \\
\hline Mura & 114,776 & 58,267 & 1,925 & 1.7 & 804 & 0.7 & 41.8 & 1.4 \\
\hline Total Slovenia & $2,066,880$ & $1,039,839$ & 121,875 & 5.9 & 43,019 & 2.1 & 35.3 & 4.1 \\
\hline
\end{tabular}

Notes Column headings are as follows: (1) number, (2) total population percentage, (3) foreign population percentage, (4) woman population percentage. Residents on 1 January 2018, ordered by female foreign presence. Based on data from Statistical Office of the Republic of Slovenia (https://www.stat.si). 
Table 2 Foreign Women in Slovenia by Country of Citizenship in the Period 2011-2018

\begin{tabular}{lrrrrrr}
\hline Country & & 2011 & 2013 & 2015 & 2017 & 2018 \\
\hline States of former Yugoslavia & $n$ & 18,953 & 23,064 & 24,115 & 28,551 & 30,673 \\
& $\%$ & 78.8 & 78.8 & 70.5 & 71.2 & 71.3 \\
\hline European Union Member States & $n$ & 2,260 & 2,906 & 6,239 & 6,838 & 7,192 \\
& $\%$ & 9.4 & 9.9 & 18.3 & 17.0 & 16.7 \\
\hline Other countries & $n$ & 2,836 & 3,294 & 3,826 & 4,735 & 5,154 \\
& $\%$ & 11.8 & 11.3 & 11.2 & 11.8 & 12.0 \\
\hline Total & $n$ & 24,049 & 29,264 & 34,180 & 40,124 & 43,019 \\
& $\%$ & 100.0 & 100.0 & 100.0 & 100.0 & 100.0 \\
\hline
\end{tabular}

Notes Residents on 1 January. Based on data from Statistical Office of the Republic of Slovenia (https://www.stat.si).

followed by Central Slovenia (7.5\%) and Litoral-Inner Karniola (6.5\%). At the administrative level in relation to absolute numbers of foreign women, the highest numbers of foreign women are in Ljubljana $(10,502)$, Maribor $(3,256)$, Koper $(2,128)$, Kranj $(1,692)$, Celje $(1,634)$ and Velenje $(1,062)$. The highest percentages of foreign women in relation to whole population are seen in the Coastal municipalities: Izola (4.9\%), Sežana (4.8\%), Koper (4.1\%).

\section{Origins and Age Structure}

Among all foreign immigrant women in Slovenia in the period 2011-2018, the highest share had arrivals from the states of former Yugoslavia, followed by European Union Member States and other countries. The available statistical

Table 3 Foreign Women in Slovenia from Main European Countries in the Period 2011-2017

\begin{tabular}{|c|c|c|c|c|c|c|}
\hline \multirow[t]{2}{*}{ Country } & \multirow[t]{2}{*}{2011} & \multirow[t]{2}{*}{2013} & \multirow[t]{2}{*}{2015} & \multicolumn{3}{|c|}{2017} \\
\hline & & & & $F$ & $F+M$ & $\mathrm{~F} / \mathrm{M}(\%)$ \\
\hline Bosnia and Herzegovina & 8,194 & 10,043 & 11,986 & 14,341 & 50,378 & 28.5 \\
\hline Kosovo & 2,457 & 3,683 & 4,653 & 5,945 & 14,397 & 41.3 \\
\hline Macedonia & 3,222 & 3,885 & 4,329 & 4,853 & 10,835 & 44.8 \\
\hline Croatia & 2,609 & 2,779 & 2,971 & 3,187 & 9,230 & 34.5 \\
\hline Serbia & 2,205 & 2,351 & 2,791 & 3,060 & 10,632 & 28.8 \\
\hline Russia & 423 & 559 & 884 & 1,310 & 2,341 & 56.0 \\
\hline Ukraine & 897 & 989 & 1,043 & 1,218 & 1,898 & 64.2 \\
\hline Slovakia & 224 & 266 & 303 & 291 & 455 & 64.0 \\
\hline Romania & 144 & 158 & 189 & 196 & 392 & 50.0 \\
\hline
\end{tabular}

Notes Resident on 1 January, ordered by female foreign presence. Based on data from Statistical Office of the Republic of Slovenia (https://www.stat.si). 
Table 4 Foreign Women in Slovenia from the Main Non-European Countries in the Period 2011-2017

\begin{tabular}{|c|c|c|c|c|c|c|}
\hline \multirow[t]{2}{*}{ Country } & \multirow[t]{2}{*}{2011} & \multirow[t]{2}{*}{2013} & \multirow[t]{2}{*}{2015} & \multicolumn{3}{|c|}{2017} \\
\hline & & & & $\mathrm{F}$ & $F+M$ & F/M (\%) \\
\hline China & 388 & 433 & 453 & 490 & 1,082 & 45.3 \\
\hline Thailand & 159 & 184 & 191 & 213 & 238 & 89.5 \\
\hline Dominican Republic & 142 & 141 & 135 & 141 & 163 & 86.5 \\
\hline Philippines & 45 & 63 & 79 & 94 & 113 & 83.2 \\
\hline Brazil & 43 & 50 & 55 & 66 & 100 & 66.0 \\
\hline Kazakhstan & 16 & 19 & 33 & 57 & 114 & 50.0 \\
\hline Japan & 26 & 31 & 36 & 41 & 79 & 51.9 \\
\hline India & 17 & 22 & 28 & 38 & 136 & 27.9 \\
\hline Turkey & 20 & 17 & 26 & 37 & 145 & 25.5 \\
\hline Iran & 10 & 11 & 17 & 31 & 90 & 34.4 \\
\hline Cuba & 23 & 22 & 25 & 30 & 58 & 51.7 \\
\hline Indonesia & 10 & 19 & 23 & 29 & 37 & 78.4 \\
\hline Columbia & 15 & 19 & 20 & 26 & 33 & 78.8 \\
\hline Syria & 4 & 4 & 16 & 24 & 84 & 28.6 \\
\hline Peru & 9 & 11 & 12 & 19 & 34 & 55.9 \\
\hline Vietnam & 4 & 10 & 12 & 18 & 19 & 94.7 \\
\hline Mexico & 9 & 12 & 15 & 16 & 41 & 39.0 \\
\hline Venezuela & 10 & 13 & 13 & 16 & 27 & 59.3 \\
\hline South Korea & 11 & 11 & 15 & 15 & 21 & 71.4 \\
\hline Nigeria & 7 & 9 & 11 & 12 & 60 & 20.0 \\
\hline Argentina & 11 & 12 & 11 & 10 & 23 & 43.5 \\
\hline Morocco & 3 & 6 & 8 & 10 & 16 & 62.5 \\
\hline
\end{tabular}

Notes Resident on 1 January, ordered by female foreign presence (the table includes countries from which the number of immigrant women exceeds 10). Based on data from Statistical Office of the Republic of Slovenia (https://www.stat.si).

data (Table 2) also tells that around 90\% of migrant women originate from European countries.

Women migrating to Slovenia mostly come from economically less developed European countries and, as already shown, mainly from the states of former Yugoslavia. As evident from Table 3, in the period 2011-2017 the highest number of women migrating to Slovenia came from Bosnia and Herzegovina $(14,341)$, followed by Kosovo $(5,945)$, Macedonia $(4,853)$, Croatia $(3,187)$ and Serbia $(3,060)$.

As evident from Table 4, the highest number of women from non-European countries migrating to Slovenia in the period 2011-2017 came from Asia, 
specifically from China (490), Thailand (213) and the Philippines (94). A significant number of women also migrated from South America, namely from the Dominican Republic (141) and Brazil (66). Meanwhile, there is a relatively low number of women immigrating from Africa (i.e. Nigeria and Morocco).

Detailed insight into the age structure of the migrant women in Slovenia is shown in the data presented in Table 5. Namely, the proportion of foreign women in Slovenia is generally higher in the age groups 30-34 years old (12.8\%) and 35-39 years old (11.3\%). Meanwhile, the average age of migrant women in Slovenia is 33.7 years. However, there are some differences in distribution regarding the continent from which the women originate - for example, in economically less developed countries (Africa, Asia, the Caribbean, South and Central America), there is a higher number of immigrants in the age group 15-54 years old, while in the case of more developed countries (North America, Australia and Oceania), relatively high numbers of immigrant women are also present in older cohorts. This could be explained by the reason for migration: whereas women from less developed countries migrate to Slovenia mainly for economic (work opportunities) and matrimonial purposes, women from more developed countries migrate for other reasons, such as searching for a better quality of life.

\section{Level of Education}

An important relationship exists between migration and education because decisions about migration and education are closely intertwined. Furthermore, level of education is of great importance in the context of reproductive health, particularly in relation to migrant women. As shown by data in Table 6 , the educational level of migrant women living in Slovenia is generally low. In 2011 and in 2015 almost 50\% of all migrant women accomplished no higher than primary school education; almost $40 \%$ had high school education and approximately $10 \%$ had higher education qualifications (university).

However, when looking more carefully at the data, one can notice big differences in education taking into account the state of origin (considering the year 2015). Comparatively speaking, women migrating from South America are the most educated (approximately $36 \%$ accomplished high school and $40 \%$ university education). Women from other European states are also well educated (one-third completed primary school, one-third high school and one-third higher education); and this is similar for women from Australia and Oceania. Approximately $40 \%$ of women from EU states have primary school education or less, $40 \%$ have high school education and only roughly $20 \%$ university education. The lowest level of education among European countries 


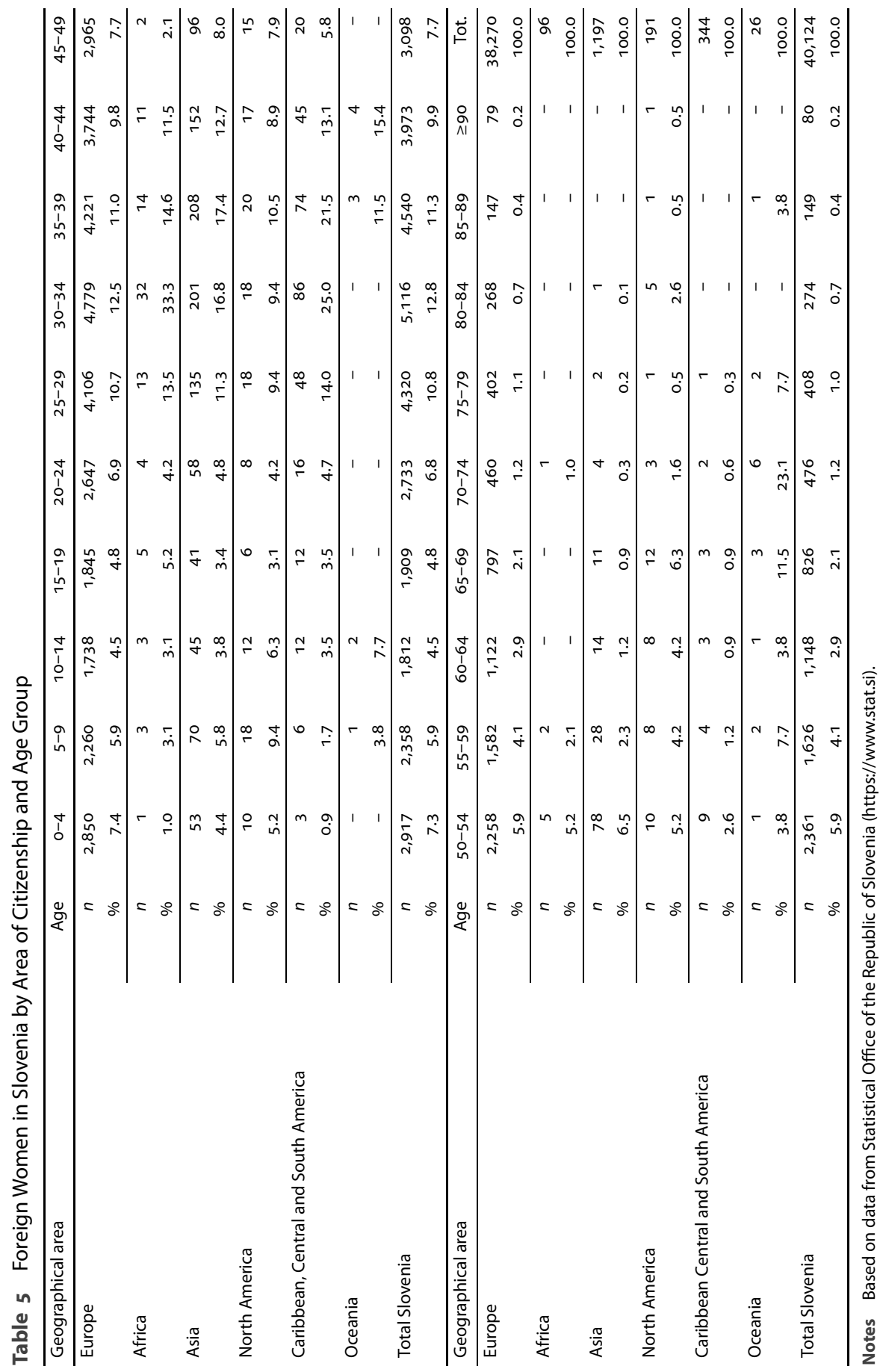


Table 6 Educational Level of Migrant Women in Slovenia (more than $15 \mathrm{y} / \mathrm{o}$ )

\begin{tabular}{|c|c|c|c|c|c|c|}
\hline & \multicolumn{3}{|c|}{2011} & \multicolumn{3}{|c|}{2015} \\
\hline & (1) & (2) & (3) & (1) & (2) & (3) \\
\hline States of ex-Yugoslavia & 41,755 & 29,045 & 8,133 & 31,615 & 21,922 & 6,056 \\
\hline EU Member States & 3,090 & 4,295 & 2,083 & 13,266 & 13,775 & 6,123 \\
\hline Other European states & 946 & 882 & 636 & 1,012 & 1,084 & 1,010 \\
\hline Africa & 60 & 77 & 33 & 67 & 80 & 47 \\
\hline South America & 100 & 123 & 107 & 87 & 130 & 146 \\
\hline North and Central America & 280 & 192 & 129 & 275 & 186 & 129 \\
\hline Asia & 338 & 305 & 121 & 380 & 435 & 211 \\
\hline Australia and Oceania & 56 & 81 & 56 & 44 & 61 & 48 \\
\hline Total & 46,625 & 35,000 & 11,298 & 46,746 & 37,673 & 13,770 \\
\hline
\end{tabular}

Notes Column headings are as follows: (1) primary school or less, (2) high school, (3) university. Based on data from Statistical Office of the Republic of Slovenia (https://www.stat.si).

was achieved by migrant women from the former Yugoslav countries: $53 \%$ accomplished no higher than primary school education, $37 \%$ high school and 10\% university.

A closer look at the educational structure of the individual states of former Yugoslavia (Table 7) reveals that there are no big differences when comparing both observed years, and that more than a half of migrant women obtained no higher than primary school education, more than one-third high school and approximately one-tenth obtained university education. Among all migrant women from former Yugoslav countries, the least educated are women from Kosovo (64\% finished primary school or less, $29 \%$ high school and only $7 \%$ university), while a relatively high educational level can be found among women migrating from Serbia.

Table 7 Educational Level of Women from the States of ex-Yugoslavia (more than $15 \mathrm{y} / \mathrm{o}$ )

\begin{tabular}{lrrrrrrrr}
\hline & \multicolumn{3}{c}{2011} & & \multicolumn{3}{c}{2015} \\
\cline { 2 - 3 } & & $(1)$ & $(2)$ & $(3)$ & & $(1)$ & $(2)$ & $(3)$ \\
\hline Bosnia and Herzegovina & 21,527 & 12,174 & 1,981 & 21,550 & 13,862 & 2,679 \\
Montenegro & 672 & 442 & 121 & 665 & 465 & 154 \\
Kosovo & 1,479 & 562 & 166 & 2,341 & 1,043 & 269 \\
Macedonia & 2,577 & 1,490 & 550 & 2,967 & 2,030 & 770 \\
Serbia & 4,229 & 4,411 & 1,880 & 4,092 & 4,522 & 2,184 \\
Total & 30,484 & 19,079 & 4,698 & 31,615 & 21,922 & 6,056 \\
\hline
\end{tabular}

Notes Column headings are as follows: (1) primary school or less, (2) high school, (3) university. Based on data from Statistical Office of the Republic of Slovenia (https://www.stat.si). 


\section{Employment Status}

Since health insurance in Slovenia depends to a large extent on an individual's employment status, it is important to consider the activities of migrant women in the labour market. As evident in Table 8 (p. 44), there are some interesting differences (considering year 2015) among migrant women according to the state of origin. Women who migrate to Slovenia from economically more developed EU Member States have different reasons compared with 'other' migrant women. The latter can also be seen from the obtained data, which show that the highest number of women from EU Member States are retired. We can anticipate that some of them came to Slovenia for reasons other than employment, such as higher quality of life, lower costs of living, safer environment, etc. Meanwhile, a significant number of migrant women from other European states (except countries of former Yugoslavia) are employed and the same is true for those who migrated from Africa, South America, North and Central America, Asia, and Australia and Oceania. Women from the states of former Yugoslavia are employed $(23,874)$ but there is a significant number of women who are unemployed $(7,385)$ or 'other' inactive $(11,284)$.

Table 9 (p. 44) is very informative, since it shows that there is quite a high number of unemployed women and women who are inactive in other ways from the states of former Yugoslavia. By far the highest number of inactive women migrating and living in Slovenia are from Kosovo. It seems that migrant women from Kosovo have in general the lowest educational level (Table 7) and are also most often unemployed or otherwise inactive. In 2015 there were more than 2000 women from Kosovo who were inactive, 600 registered as unemployed, and only 509 employed. It can be assumed that those registered as 'other inactive' are housewives who are not actively searching for a job, as those searching for a job would be registered as unemployed. Also, numbers from 2015 showing the situation for women coming from Macedonia reveal a very high number of inactive women - 1,682 in comparison with 1,974 employed (in addition to 771 unemployed). It can be anticipated that among them the biggest number represent ethnic Albanian women, so that the pattern of in/activity is very similar to those of women coming from Kosovo.

\section{(Reproductive) Health in Relation to Migrant Women in the National Legislation}

As already mentioned, reproductive health represents one of the individual's universal rights framed in the international human rights instruments and 


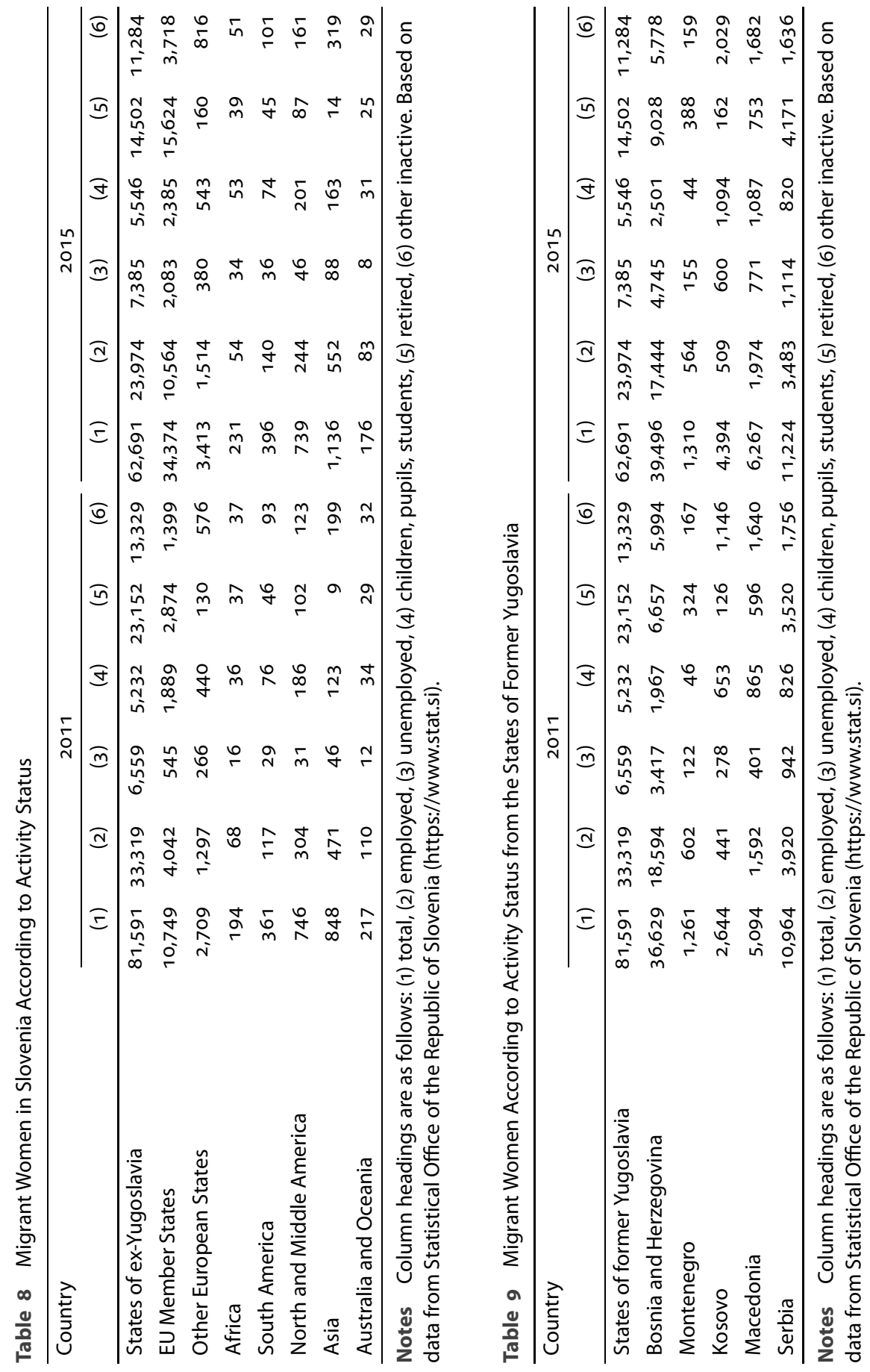


individual national legislation. ${ }^{2}$ Slovenia is a signatory of the main human rights documents (e.g. International Bill of Human Rights, Convention on the Rights of the Child, Convention on the Elimination of All Forms of Discrimination Against Women), through which it commits to ensure the right to reproductive health, as a part of the right to health. As an EU Member State, Slovenia is also obliged to respect documents concerning the area of reproductive health that were produced by the European Union (e.g. Charter of Fundamental Rights of the European Union, Health 2020: A European Policy Framework Supporting Action Across Government and Society for Health and WellBeing, EU Guidelines on Violence against Women and Girls and Combating all Forms of Discrimination against Them), although primary responsibility for regulating these rights lies with the country itself, which is to some extent independent in establishing its own (reproductive health) system.

In Slovenia access to public health services depends on an individual's compulsory health insurance, which is financed mainly by taxes, but does not cover all treatment costs. According to national legislation, i.e. Health Care and Health Insurance Act, ${ }^{3}$ full-coverage healthcare insurance is ensured for systematic and other preventive examinations of underaged children, pupils, students up to 26 years old, women in relation to pregnancy and other adult persons with certain health conditions (Article 23). The main legal documents regulating healthcare in Slovenia are the Constitution of the Republic of Slovenia, ${ }^{4}$ Health Service Act (1992), Patients' Rights Act, ${ }^{5}$ and Health Care and Health Insurance Act. It is important to mention that the Constitution of the Republic of Slovenia does not explicitly provide the right to health but foresees the right to health insurance (Article 50), healthcare (Article 51) and a healthy living environment (Article 75). According to the Constitution, all rights related to health are realized in accordance with the law that can set the conditions for carrying and exercising these rights.

According to legislation, migrants' entitlements to health services depend on their legal status: migrants with legal status are covered by the same healthcare system as citizens. Articles 15 and 20 of the Health Care and Health Insurance Act define on what grounds an individual is insured, the main criterion being employment in the Republic of Slovenia. Concerning underage

\footnotetext{
${ }^{2}$ All quoted laws, rules and guidelines are translated by the authors, because official English language translations are not available.

${ }^{3}$ Zakon o zdravstvenem varstvu in zdravstvenem zavarovanju, see http://www.pisrs.si/Pis.web/ pregledPredpisa?id=ZAKO213.

${ }^{4}$ Ustava Republike Slovenije, see http://www.pisrs.si/Pis.web/pregledPredpisa?id=USTA1.

${ }^{5}$ Zakon o pacientovih pravicah, see http://pisrs.si/Pis.web/pregledPredpisa?id=ZAKO4281.
} 
children, Lipovec Čebron, Zorn, Pistotnik, \& Meh (2016) stress that they have special protection regarding access to the healthcare system. Namely, the Health Care and Health Insurance Act (Article 15, Point 24) extends the right to healthcare to all minors enrolled in school, even if they do not have health insurance, citizenship or permanent residency status.

As the supreme law of the country, the Constitution of the Republic of Slovenia stipulates in Article 55 that 'individuals have freedom to decide on the birth of their own children. The state provides opportunities for exercising this freedom and creates such conditions as will enable parents to decide to have children.' This right is governed by the Health Measures in Exercising Freedom of Choice in Childbearing Act, ${ }^{6}$ which regulates the conditions under which the right of prevention of conception (Chapter II), abortion (Chapter III), diagnosis and treatment of impaired fertility (Chapter IV) are exercised. Legislation also dealing with reproductive health is Rules on Carrying out Preventive Health Care at the Primary Level, ${ }^{7}$ which initially explains that reproductive health ensures 'the right to a satisfying and safe sexual life, to decide freely on childbirth, to equal access to information on family planning and reproductive health regardless of gender, to safe and effective methods of family planning and the right to health services which provide women with a safe pregnancy and childbirth, and effective prevention and early detection of diseases that cause premature morbidity and mortality.' Furthermore, the document defines the following areas of reproductive health:

- the content of prevention programmes (family planning, use of contraceptives, sexually transmitted infections and subsequent infertility, preventive examinations during pregnancy, examinations and counselling after childbirth, spontaneous and permitted terminations of pregnancy and ectopic pregnancy, preventive activities for the protection of reproductive health in nursing care, preventive screening for the different types of cancer);

- programmed health education and health promotion in primary healthcare for women (guidelines for the protection of reproductive health of population groups with increased risk, guidelines for health education work with young people and with women before and after a permitted abortion and prenatal health education);

\footnotetext{
${ }^{6}$ Zakon o zdravstvenih ukrepih pri uresničevanju pravice do svobodnega odločanja o rojstvu otrok, see http://pisrs.si/Pis.web/pregledPredpisa?id=ZAKO408.

${ }^{7}$ Pravilnik za izvajanje preventivnega zdravstvenega varstva na primarni ravni, see http://www .pisrs.si/Pis.web/pregledPredpisa?id=NAVO59.
} 
- contractors of reproductive health prevention programmes (methods of implementation, coordination and control).

In addition, family members of migrants with permanent residence status can be insured on the basis of Article 20 of the Health Care and Health Insurance Act; namely, as close (spouses and children) or as extended family members (grandchildren, brothers, sisters and other children who live with the insured person in a common household and do not have sufficient means of subsistence and are permanently and completely incapable of work). Also, able to be insured under the extended family category are the father and mother of the insured person, or a spouse or cohabiting partner who live in the same household and are economically dependent on the insured person and are permanently and completely incapable of work.

Migrants who are not included in the health insurance system (asylum seekers and illegal migrants) have the right to emergency healthcare services, which, according to the Health Care and Health Insurance Act (Article 7), encompass 'urgent treatment of persons of unknown residence, aliens from countries which have not concluded an international agreement, as well as aliens and citizens of the Republic of Slovenia with permanent residence abroad who are temporarily residing in Slovenia or are travelling through the country and were unable to obtain payment for medical services, as well as for other persons who, under the provisions of this Act, are not included in the compulsory health insurance and are not insured with a foreign health insurance holder.' Situations of emergency care are defined in more detail in Article 25 of this Act: urgent treatment comprises essential rescusitation services, preservation of life and prevention of the deterioration of the health status of the sick or injured. The urgency of treatment is evaluated by a personal physician or competent medical committee in accordance with the general acts of the institution. The scope and situations of emergency medical help are also explained by the Rules on Compulsory Health Insurance, ${ }^{8}$ which, in Article 103 , specify that emergency medical help embraces rescusitation services, services necessary for maintaining life functions, services for the prevention of sudden serious deterioration of the ill person's health condition, treatment of injuries and chronic illness. The emergency healthcare services to asylum seekers are accurately defined in Article 86 of the International Protection Act, which, among other things,

\footnotetext{
${ }^{8}$ Pravila obveznega zdravstvenega zavarovanja, see http://www.pisrs.si/Pis.web/ pregledPredpisa?id=PRAV 3562 .
} 
regulates healthcare for women (contraception, abortion, healthcare during pregnancy and while giving birth). ${ }^{9}$

\section{Existing National Topic-Related Literature}

Reproductive health in relation to migrant women is an under-researched topic in Slovenia. However, there are a few articles which deal with the issue of reproductive health and indirectly mention migrant women as a vulnerable group that demands special attention. In addition, the academic literature on health issues of migrants encompasses a range of views from disciplines including social work, law, anthropology, sociology and health sciences as well.

The literature review revealed that health issues in relation to immigration began to generate attention among academics from the late 1990s, with the arrival of refugees from the countries of former Yugoslavia. For example, in their 2010 literature review Bufolin and Bešter cite Health Protection of Special Social Groups published in 1996 by the National Institute for Public Health, in which refugees and migrants were recognized as special social group. In this volume Mikuš Kos (1996) published an article theorizing on the issue but emphasizing that there are among migrants and refugees certain characteristics (e.g. high level of mortality, modest use of support services, lack of knowledge of (health) rights, low quality of life, high degree of dissatisfaction with life, poor functional literacy and marginalization) which make them vulnerable and consequently require special attention. Some of the earliest empirical work related to the reproductive health of women in Slovenia came from the field of social work. In 2005 Ličer published an article entitled 'Social Aspects of Women's Reproductive Health Protection.' For the purposes of her study she conducted ten interviews with women who went through their pregnancy without regular gynaecological examinations (not by choice); two women from the sample were immigrants. The results of the study revealed that for all women included in the sample the main reasons for not attending gynecological examination during the pregnancy derived from unregulated medical insurance, time constraints of being a single mother and privacy issues in the treatment room. The common denominator in the sample of interviewees was difficult socio-economic circumstances (unemployment, single-parent family and social exclusion). Based on the study results, it can be concluded that women have less information about reproductive health (1) when they are out of regular education and employment, (2) where ac-

\footnotetext{
${ }^{9}$ Zakon o mednarodni zaščiti, see http://pisrs.si/Pis.web/pregledPredpisa?id=ZAKO7103.
} 
cess to a gynecological clinic in their place of residence is problematic, and (3) where there is inconsistent respect for privacy, confidentiality and the right to make an independent decision on pregnancy.

Another important issue concerning the reproductive health of migrant women is access to medical services. There have been recent efforts to improve knowledge of (equal) access to health services of immigrants, which is reflected in the fact that a majority of available literature deals with the issue. Thus, Bufolin and Bešter (2010) have questioned the existence of inequalities between immigrants and non-immigrants regarding access to health services, their quality and general satisfaction with healthcare. Their study revealed that, with the (partial) exception of applicants for international protection and refugees, immigrants in the Slovenian health system are not recognized as a group that should have special attention in healthcare and integration policies. Their results indicated that the main problems faced by immigrants in the Slovenian health system include: language barriers, lack of intercultural competences of health personnel and their (hidden) discriminatory relationship towards migrants. These factors were also confirmed as a main source of unequal access to the health system in a recent study implemented by Lipovec Čebron (2017).

Healthcare as a human right is the starting point of the article published by Rajgelj (2012). Because of its universal status, an individual is entitled to healthcare regardless of his/her personal circumstances, but in the legislative process different systems have different criteria for the accessibility and funding of this right. In the case of Slovenia, the author observed how respective social priorities affect inclusion and exclusion of beneficiaries of healthcare on the ground of their legal status. To that end, she analyzed national and international legislation regarding the constitutional right to healthcare, health insurance, employment and family relations. Based on the analysis, the conclusion was drawn that since the enjoyment of the right of health insurance depends on an individual's employment, citizenship and family status, users of healthcare are treated unequally. The author also emphasizes that the most vulnerable group in the context of the access to health are immigrants without permanent residence.

Although in Slovenia applicants for international protection are eligible (only) for emergency treatment, research has identified several discrepancies between the rights afforded on paper and experiences in practice. Two similar studies were implemented with the purpose of examining conditions and opportunities for applicants for international protection to have access to health services. Lipovec Čebron (2009) and Jazbinšek and Palaić (2009) 
conducted interviews with employees in Asylum Home and applicants for international protection. Based on the data obtained, both studies came to the identical conclusion that health treatment for applicants for international protection in Slovenia is, in the majority of cases, inappropriate and limited. One of the main obstacles is the legally defined right to emergency health treatment, because it is not clear what exactly this means, and as such it can be subject of different interpretations.

Another important work regarding migrants' access to health services was published by Lipovec Čebron (2010). The author begins from the concept of medical citizenship and argues that it is an important category in examining the healthcare aspects of migration to Slovenia. Namely, the welfare services that had been available to all citizens prior to Slovenian independence in 1991 were converted into a source of inequality and exclusion after that date. 'Health policy has consistently become less socially oriented, as is reflected in increasingly restrictive and selective access to health services - or in other words, restrictive and selective medical citizenship in Slovenia' (Lipovec Čebron, 2010, p. 193). However, the main goal of this research is to prove that the seemingly regulated access to medical services still often deprives migrants of their medical entitlements. The author starts from the assumption that due to their frequent failure to assert healthcare rights, it is very important for migrants how health workers perceive them. To that end empirical data were obtained by interviews with health workers and administrative staff in Ljubljana and in the Slovenian part of Istria who had the most frequent contacts with the immigrant population. ${ }^{10}$ Based on the comments of medical professionals, the author concludes that their views of people without health insurance mirror neoliberal health policies. Namely, 'they perceive them as "foreigners" who should be taken care of in other countries, as a disorderly, "impure," "incompetent" people who represent a "burden" for the Slovenian health system' (Lipovec Čebron, 2010, p. 207).

In recent decades, researchers have identified the great impact of socioeconomic factors on various health outcomes. The results of a recent comprehensive health study were published in the report Inequalities in Health in Slovenia (Buzeti et al., 2011). Although the study does not mention immigrants specifically, it offers detailed insight into the sphere of inequalities in

\footnotetext{
${ }^{10}$ The survey included 42 persons: unstructured and semi-structured interviews were conducted with 13 specialist medical doctors, four general practitioners and six nurses. Responses to the questionnaire were received from five specialist medical doctors, three general practitioners and 11 administrative workers from healthcare institutions.
} 
health and identifies key challenges that Slovene society must face in the future if it wants to successfully manage health inequalities. One of main challenges, which is also evident from the reviewed scientific literature dealing with the topic, is that as a country we need a new vision for reducing inequalities in health. To that end, a strategic national framework (health policy) must be prepared, which will set out coordinated objectives and priorities for different sectors at national and local level. It is also important that individual departments at different levels recognize the benefits of reducing health inequalities, which can then contribute towards establishing more coherent sectoral and cross-sectoral policies. As the authors of the study argue, the prerequisite for planning and action in relation to health inequalities is the systematic monitoring of the situation and trends, which is the basis for designing measures and evaluating the achievement of the set goals. Collecting data at different levels is a prerequisite for the systematic monitoring, analysis and evaluation of health inequalities and the set goals.

At this point it is important to stress that at the national level no information is officially and systematically collected about the health of migrants (and migrant women) or of healthcare services that they use. According to the Healthcare Databases $\mathrm{Act}^{11}$, health providers are not required to collect data on a patient's nationality or his/her country of origin. Furthermore, the Act stipulates that if personal data relate to racial, national or other origin, political, religious or other beliefs or sexual orientation, database administrators may obtain this information directly or indirectly only with the written consent of the individual. The present situation makes it impossible to obtain information regarding reproductive health in relation to migrant women.

Reproductive health is closely related to gender-based violence, ${ }^{12}$ but this topic is also rarely addressed in public discourse and, unfortunately, hardly ever in scientific studies. However, research was recently implemented by Vah Jevšnik (2016) in which the impact of immigrant status on the vulnerability of migrant women in the context of family violence was observed. According to the research, migration status can significantly influence fre-

\footnotetext{
${ }^{11}$ Zakon o zbirkah podatkov s področja zdravstvenega varstva, see http://www.pisrs.si/Pis.web/ pregledPredpisa?id=ZAKO1419

${ }^{12}$ In Slovenia the term gender-based violence is used interchangeably with the term violence against women (Resolution on the National Program for Equal Opportunities for Women and Men 2015-2020 (Resolucija o nacionalnem programu socialnega varstva za obdobje 2013-2020, see http://www.pisrs.si/Pis.web/pregledPredpisa?id=NACP68), as most gender-based violence is inflicted by men on women and girls, although we must not overlook the fact that victims of gender-based violence can be also men.
} 
quency, responses and measures of violence against migrant women, as well as the support provided by public services. This leads to the conclusion that women who are in the country with unregulated legal status are even more vulnerable than those obtaining legal status; since illegal migrant women do not have a legal personal income, they are consequently not entitled to social benefits and support services provided by public institutions. In other words, they depend on the perpetrator and live in fear of deportation. With the purpose to obtain qualitative data, Vah Jevšnik (2016) conducted 30 interviews with professionals working with victims of gender-based violence, one of them being employed in Asylum Home. The study identified several risk factors in this social group, among which the most important are: lack of information regarding support systems, language barriers, mistrust and suspicion towards professional workers (especially men), absence of social networks, problems with integration, prejudice and discrimination against their way of life, low socio-economic status and low level of education.

\section{Best Practices Overview}

As evident from the review of national legislation and scientific literature, the specific needs and rights of migrant women in relation to reproductive health lack attention. Persistent efforts to resist this trend nonetheless make it possible to identify examples of good practice which are presented below.

As discussed above, migrant women in Slovenia are recognized as an especially vulnerable group and as such they have also limited access to a range of (reproductive) health information and services. With the purpose to improve access to healthcare services for different vulnerable groups in Slovenia, a chain of clinics (i.e. Pro Bono Clinic) was established. These clinics are intended for persons without medical insurance, such as people who are not residents in the territory of the Republic of Slovenia, asylum seekers, rejected asylum seekers, illegal refugees and refugees. Currently, there are four clinics located in Ljubljana, Maribor, Koper and Kranj. In the context of improving access to healthcare services, it is necessary to mention the project Towards Better Health and Reducing Inequalities in Health (2013-2016, financed by the Norwegian Financial Mechanism Programme). The first aim of the project was to recognize different vulnerable groups of the population of Slovenia which face difficulties with access to the healthcare system as well as barriers within health institutions. Among these groups were migrants, especially migrant women. With the purpose of improving access to these groups, several suggestions (legislative, administrative) were developed and transmitted to the competent authorities (Ministry of Health, Ministry of Labour, Family, So- 
cial Affairs and equal opportunities). Translated and adapted to the national context was the Standard for Equity in Health Care for Vulnerable Groups (Farkaš \& Lipovec Čebron, 2016), which was originally produced by the International Network of Health Promoting Hospitals and Health Services. The tool is designed as a 'barometer' for discrimination in the health sector and allows health institutions to find out the level of inclusion of different marginalized or socially weak groups in their services. At the final conference of the project, a Declaration on the Importance of Implementation of Intercultural Mediation in Healthcare Institutions in Slovenia was presented (Farkaš et al., 2016). Throughout the project, solutions were also introduced at a local level. One of them was in the city of Celje where it became evident that women from Albania faced language and cultural obstacles in health institutions. In an attempt to overcome these obstacles, an intercultural mediator was introduced in the local community, who was trusted by the Albanian community and at the same time possessed good knowledge of both the Slovenian and Albanian languages. During the project a pilot interdisciplinary educational course was also developed, titled Training for Development of Intercultural Competencies of Health Professionals, which was implemented in three public healthcare centres (Sevnica, Vrhnika and Celje) from February 2015 to March 2016.

As revealed by the literature review, migrant women face twofold difficulties in obtaining information and available services regarding reproductive health: the first obstacle is language and cultural barriers and the second is the absence of appropriate dissemination of already scarce existing information. This paradoxical situation is to a certain degree solved mainly by NGOs (specifically Slovenian Philanthropy) which offer various mainly project-based information services for migrants and provide cultural mediators for migrants in healthcare institutions.

In the context of gender-based violence and reproductive health, the project Recognizing and Treating Victims of Domestic Violence in Healthcare Settings should be mentioned (implemented during the period 20092014), which was co-financed by the Norwegian Financial Mechanism Programme. Specific project goals were: (1) implementation of the Family Violence Prevention Act in the health sector; (2) education of health workers based on professional guidelines for responding to violence against women in healthcare settings (developed by the Ministry of Health of the Republic of Slovenia); (3) increasing clinical, communication and cultural competencies of health workers to recognize and treat victims of domestic violence and to work with vulnerable groups; and (4) establishing intersectoral treat- 
ment of victims and perpetrators of violence against women comparable with international practices. The main outcome of the project was the publication of Recognizing and Treating Victims of Domestic Violence in Healthcare Settings: Guidelines and Training for Health Professionals (Šimenc, 2015) suggesting recommended conduct in responding to child victims of abuse and violence and adult victims of violence. The guidelines aim to equip health professionals encountering victims of violence with basic skills and knowhow for identifying abuse and properly responding to it.

In 2015 the Ministry of Health of the Republic of Slovenia adopted Professional Guidelines for Addressing Domestic Violence in The Implementation of Healthcare Activities (Ministrstvo za zdravje, 2015) which contained a series of recommended practices, steps for the treatment of child victims of abuse and violence and adult victims of violence against women, for various health professionals who may encounter this kind of violence. Specific guidelines have been developed for dealing with victims of domestic violence in hospitals and in gynecology and obstetrics, used in accordance with basic medical ethical rules.

\section{Conclusions}

In Slovenia a comprehensive and systematic approach to reproductive health in relation to migrant women is missing. The first major issue is the absence of a national periodical study on the topic. Systematic collection of data on migrant women included in the health insurance system and excluded from it should be started. This is necessary step and a base for any further measures in the field.

Data on the number of migrant women in Slovenia show that their number is constantly increasing (a six-fold increase between 1995 and 2016) and it is expected that it will be even higher in the future. The majority of migrant women come from the states of former Yugoslavia (Bosnia and Herzegovina, Kosovo, Macedonia and (roatia) and they migrate mostly for economic reasons (work) and family reasons (following husbands). Meanwhile, women from economically richer countries are migrating to Slovenia mostly for reasons connected with a better quality of life. The educational level of women migrating to Slovenia is relatively low, since almost $50 \%$ of all migrant women accomplished no higher than primary school education, which has crucial consequences for the information about and accessibility to reproductive health services. In general, one of the most marginalized groups of migrant women in Slovenia is Albanian women from Kosovo and Macedonia, who have the lowest educational level in comparison with all other 
migrant women; they are to a large extent non-active on the labour market (unemployed, but not registered as job seekers) and, finally, they mostly do not have Slovenian citizenship, do not speak the Slovenian language and do not have contacts and a social life outside the (extended) family and ethnic community. Due to the language barriers and other cultural and traditional norms (patriarchal values), it is a husband or male relative (e.g. father-in-law) who communicates with the 'outside' world on her behalf. As empirical studies show, this situation also has important implications for the reproductive health of these women (Sedmak, Medarić, Lenarčič, \& Gornik, 2018).

Although international and EU documents refer to health as a human right, specific needs and rights, in particular regarding reproductive health, are currently not ensured through Slovenian legislation. This is particularly true for migrant women with irregular status who have limited access to services of any kind beyond emergency care (and even for this service it is not clear exactly what it encompasses) through the public health system, including those related to their reproductive health rights. Similar findings were reported in studies dealing with the issue of equal access to health services among immigrants. Besides barriers specifically linked to their legal status, migrant women also face obstacles related to their status as foreigners, which results in limited familiarity with the national health system, different customs and experiences related to sexual and reproductive health, and languages that may be unfamiliar to healthcare practitioners. In this respect, several empirical studies have identified the main obstacles in accessing (reproductive) health services as being language barriers, lack of intercultural competences of health personnel and their (hidden) discriminatory relationship towards migrants. Resulting from this, it is clear that in Slovenia there exist quite a few discrepancies between the rights afforded on paper and the experiences of migrant women in practice. Although the activities of several NGOs aim to raise awareness about reproductive health in relation to migrant women, the literature review indicates that this is an under-researched field in Slovenia and we still lack theoretically and empirically supported analysis. The bottom line is that assessment of the current situation in Slovenia clearly unveils both blurred legal and policy frameworks and patchy practices, which are major shortcomings in terms of the realization of a rightsbased approach to reproductive health in relation to migrant women. The literature review and best practices overview indicate that the first and the most urgent step towards improvement of the situation would be to educate health providers interculturally in order that they can recognize reproductive health norms and practices within different cultural contexts. This 
would allow them to provide culturally safe medical care, health education, and health promotion, and finally increase access to reproductive health for migrant women.

\section{References}

Bofulin, M., \& Bešter, R. (2010). Enako zdravstvo za vse? Imigranti v slovenskem zdravstvenem sistemu. In M. Medvešek \& R. Bešter (Eds.), Državljani tretjih držav ali tretjerazredni državljani? Integracija državljanov tretjih držav $v$ Sloveniji (pp. 270-311). Ljubljana, Slovenia: Inštitut za narodnostna vprašanja.

Buzeti, T., Djomba, J. K., Gabrijelčič Blenkuš, M., Ivanuša, M., Jeriček Klanšček, H., Kelšin, N., ... Zver, E. (2011). Neenakosti v zdravju v Sloveniji. Ljubljana, Slovenia: Inštitut za varovanje zdravja.

Farkaš Lainščak, J., \& Lipovec-Čebron, U. (Eds.). (2016). Standard za zagotavljanje enakosti v zdravstveni oskrbi 'ranljivih' skupin in orodje za samoocenjevanje zdravstvenih ustanov. Ljubljana, Slovenia: Nacionalni inštitut za javno zdravje.

Jazbinšek, S., \& Palaić, T. (2009). Zdravje - človekova pravica? Prosilke in prosilci za mednarodno zaščito. Časopis za kritiko znanosti, 37(238), 154-162.

Keygnaert, I., Guieu, A., Ooms, G., Vettenburg, N., Temmerman, M., \& Roelens, K. (2014). Sexual and reproductive health of migrants: Does the EU care? Health Policy, 114(2/3), 215-225.

Ličer, Z. (2005). Socialni vidiki varovanja reproduktivnega zdravja žensk. Socialno delo, 44(6), 377-385.

Lipovec Čebron, U. (2009). Od kulture nezaupanja do selektivnega sočutja: prosilci in prosilke za mednarodno zaščito v slovenskem zdravstvenem sistemu. Časopis za kritiko znanosti, 37(235/236), 190-203.

Lipovec Čebron, U. (2010). The construction of a health uninsurant: People without medical citizenship as seen by some Slovene health workers. Studia ethnologica Croatica, 22, 187-212.

Lipovec Čebron, U. (2017). Ko nujno postane nenujno: raziskovanje zdravstvenih vidikov migracije v Slovenije. Glasnik Slovenskega etnološkega društva, $57(1 / 2), 54-64$.

Lipovec Čebron, U., Zorn, J., Pistotnik, S., Meh, E. (2016). MIPEX health strand: Country report Slovenia. Retrieved from http://www.nijz.si/sites/www.nijz .si/files/uploaded/podatki/slovenia_mipex_health.pdf

Mikuš Kos, A. (1996). Promocija zdravja migrantov in beguncev. In E. KraševecRavnik (Ed.), Varovanje zdravja posebnih družbenih skupin v Sloveniji (pp. 73109). Ljubljana, Slovenia: Inštitut za varovanje zdravja republike Slovenije.

Ministrstvo za zdravje. (2015). Strokovne smernice za obravnavo nasilja v družini pri izvajanju zdravstvene dejavnosti. Ljubljana, Slovenia: Author.

Rajgelj, B. (2012). Vpliv delovnopravnega, državljanskega in družinskopravnega 
statusa na neenako obravnavo v zdravstvenem zavarovanju. Zdravstveno varstvo, 51(1), 43-52.

Sedmak, M., Medarić, Z., Lenarčič, B., Gornik, B. (2018). Spolno in reproduktivno zdravje migrantkv Sloveniji:Študija primera treh obalnih občin. Koper, Slovenia: Znanstveno-raziskovalno središče Koper.

Šimenc, J. (Ed.) (2015). Prepoznava in obravnava žrtev nasilja v družini: priročnik za zdravstveno osebje. Ljubljana, Slovenia: Zdravniška zbornica Slovenije.

United Nations Population Information Network. (1994). Guidelines on reproductive health. Retrieved from http://www.un.org/popin/unfpa/taskforce /guide/iatfreph.gdl.html

Vah Jevšnik, M. (2016). Vpliv migracijskega statusa na ranljivost žrtev nasilja v družini. Socialno delo, 55(1-2), 67-76.

S. Ličen, I. Karnjuš, \& M. Prosen (Eds.). (2019). Women, migrations and health: Ensuring transcultural healthcare (pp. 35-57).

Koper, Slovenia: University of Primorska Press.

https://doi.org/10.26493/978-961-7055-43-6.35-57 